\title{
Analysis of Gaps Among Stakeholders of Occupational Health and Safety in the Philippines
}

\author{
Paul Michael R. Hernandez and Arra Shayne B. Saquido \\ Department of Environmental and Occupational Health, College of Public Health, University of the Philippines Manila
}

\begin{abstract}
Objective. Increase of occupational injuries, accidents or diseases, has become a global trend. Implementation of programs on Occupational Health and Safety (OHS) programs are weak, however. Strengthening the OHS, stakeholders and their constituents must take the driver's seat for policy formulation program development and services. This study determined the gaps of the OHS stakeholders in the Philippines.

Methods. Data were gathered through review of relevant documents, series of key informant interviews and a workshop.

Results and Conclusions. The investigators were able to identify 27 stakeholders. Results showed gaps that focused mainly on governance. These include: (1) lack of a dedicated national agency that will oversee all OHS initiatives across industries and sectors; (2) inadequate awareness on OHS mandate of some agencies; (3) unclear delineation of roles and responsibilities among stakeholders; (4) poor coordination among government agencies; and (5) poor enforcement of OHS legislations. These gaps should be addressed to ensure effective and efficient implementation of the policies.
\end{abstract}

Key Words: gaps among stakeholders, occupational health and safety, stakeholder framework

\section{INTRODUCTION}

Presented at the 7th International Graduate Students Conference on Population and Public Health Sciences in the Chulalongkorn University College of Public Health Sciences, June 10, 2016, Bangkok, Thailand

Corresponding Author: Paul Michael R. Hernandez MD, MOH Department of Environmental and Occupational Health College of Public Health

University of the Philippines Manila

625 Pedro Gil Street, Ermita Manila 1000 Philippines

Telephone: +6325247102

Email: prhernandez@up.edu.ph
According to the Joint Committee of the World Health Organization (WHO) and the International Labor Organization (ILO), Occupational Health (OH) has four (4) aims: (1) promote and maintain the highest degree of physical, mental, and social wellbeing of workers in all occupations; (2) prevent illness caused by their working conditions; (3) protect workers from risks resulting from factors adverse to health; and (4) place and maintain the worker in an occupational environment that is suited to him or her. However, global trends show that occupational health and safety concerns revolve around the increase of occupational injuries, accidents or diseases. This could mean that the implementation of Occupational Health and Safety (OHS) programs are rather weak. Thus, there is a need to strengthen the OHS, and in order for this to materialize stakeholders and their constituents must ensure that policy formulation, program development and services are provided and implemented accordingly. ${ }^{1-3}$

Countries such as Finland, Malaysia, Thailand, Singapore and Australia have strong Occupational Safety and Health programs and active stakeholders, which ensures that $\mathrm{OSH}$ programs and services are delivered. Finland's main stakeholders include: (1) Ministry of 
Social Affairs and Health (DOSH, DPWH), (2) Ministry of Employment and Economy, (3) Social Partners, (4) Research and Advisory Support. Meanwhile, Malaysia's stakeholders include: (1) Government Agencies, (2) Social Partners, (3) GLCs, (4) OSH Practitioners, (5) Universities, (6) Industries. Thailand's stakeholders include: (1) Ministry of Labor, (2) Ministry of Public Health, (3) Ministry of Industry and (4) Other OSH agencies, associations and organizations. Singapore's major stakeholders, on the other hand, include: (1) Ministry of Manpower, (2) Work Safety and Health Council, (3) Work Safety and Health Institute, (3) Industry Association and (4) Professional Bodies. Meanwhile, Australia has its own independent agency, the Safety Work Australia.

The aforementioned agencies' major functions are: (1) $\mathrm{OSH}$ administration and enforcement, (2) Provision of training, (3) Research and development, (4) OSH Promotion, (5) Information dissemination, and (6) Statistics. ${ }^{4-8}$

In the Philippines, the Inter-Agency Committee for Environmental Health (IACEH) was created under the Executive Order No. 489. It consists of government agencies whose main functions are to: a) Formulate policies and guidelines and develop programs; b) Coordinate, monitor, and evaluate Environmental Health (EH) programs and development projects; c) Undertake information dissemination and education campaigns on $\mathrm{EH}$ programs; d) Coordinate, assist and/or support the conduct of research and relevant activities for environmental maintenance and protection. In which, a specific Occupational Health Subsector is also part of the taskforce. However, problems in OHS implementation are still present. For instance, private sectors are not included in the committee, even though they are the most regulated sector by the government. Moreover, some of the agencies involved assume more than one function in the implementation of OHS. ${ }^{9}$

To address this, the call to strengthen the National Occupational Health and Safety ensued last 2013. Part of this project is the development of the National Occupational Health and Safety system which resulted to the OHS stakeholder framework. The system was composed of organizations, people and actions whose primary intent is to promote, restore or maintain health. ${ }^{10}$ It focuses on the World Health Organization's System classification of primary functions: (1) Health workforce (2) service delivery, (3) information and research (4) medical products and technologies (5) health care financing (6) good leadership and governance. Various institutions were identified as a stakeholder, which will efficiently implement aforementioned health system functions that will serve as the driving force of the system.

In support, various literature showed the importance of stakeholder engagement. Engagement from the stakeholders contribute to the success of the projects at hand. ${ }^{11}$ Aforementioned countries' occupational health and safety stakeholders play a big role in implementing and developing systems to ensure the success of Occupational health and safety in their countries. However, this could differ with our country, as the OHS stakeholders in the Philippines assume more than one role.

This study was undertaken to determine gaps of the OHS stakeholders of the Philippines. This will aid in providing appropriate recommendations that will ultimately be a source of reference to improve the functionality of the OHS system and stakeholders of the country.

\section{METHODS}

The study is a descriptive study design. The document utilized were prepared and developed under the supervision of the Department of Health (DOH), during the phase one of the project "Strengthening of the National Occupational Health and Safety in the Philippines." Data validation and gap analysis were done through the following:

\section{Review of Relevant Documents}

Literature search on various search engines such as Google Scholar, MEDLINE, PubMed and websites of the World Health Organization and International Labor Organization regarding global occupational health and safety framework was also done. Key words used were "occupational health and safety," "national profile," and "stakeholder framework." Articles only included were those in English format. Moreover, a review of agencies' mandates was done to be able to identify the occupational health and safety stakeholders together with their functions.

\section{Key Informant Interviews}

The key informant interviews were conducted to fully understand the scope of the roles and responsibilities of the Stakeholders. Note that stakeholders are part of the Inter-Agency Committee for Environmental Health. The questions in the KII included the following topics specifically on Occupational Health and Safety: (1) legal mandate, (2) roles and responsibilities, (3) information dissemination, (4) self-assessment on institution performance in fulfilling their roles and responsibilities, and (5) issues and gaps in the implementation in the country. The method of analysis utilized is content analysis of the common themes stated by the stakeholders.

Results from the review of relevant documents and key informant interviews yielded the development of the framework, which was presented in the workshop.

\section{Workshop}

The workshop was facilitated in order to fully develop the Occupational health and safety stakeholder framework. However, only ten (10) out of 27 Inter-Agency Committee for Environmental Health (OH subsector) stakeholders were able to attend the said workshop. The results from the key informant interviews were presented in this workshop, it was 
also then that the roles and responsibilities were clarified, and the categorization for the framework took place. The method of analysis for the workshop is the content and thematic analysis that paved way in confirming the roles and responsibilities for each stakeholder and determining the gaps and issues.

\section{Limitations of the study}

The study also encountered limitations in the study such as time constraints due to limited time of project implementation. There was a lack of stakeholder involvement as only ten (10) of 27 Inter-Agency Committee for Environmental Health ( $\mathrm{OH}$ subsector) stakeholders participated in the workshop, and that not all stakeholder evaluation methods were exhausted.

\section{Ethical Clearance}

Ethical clearance was not obtained because the end-users of the results of the project entitled "Strengthening of the National Occupational Health and Safety in the Philippines" is the Inter-Agency Committee for Environmental Health and as such, the study was part of the monitoring and evaluation of their stakeholders. Moreover, there was an urgency in the implementation of the project, that did not allow to acquire clearance.

\section{RESULTS}

The investigators reviewed six (6) National Occupational Health and Safety Profiles, ranging from developed to developing countries near the Philippines. Countries included were the following: Singapore, Malaysia, Thailand, Finland, Australia and Philippines. The review on the occupational health and safety stakeholders of other countries depicted similar major stakeholders, which are: (1) Ministry of Health, (2) Ministry of Labor, (3) Employees, (4) Employers, (5) Higher Education Institutions, and (6) Professional Bodies. While, Australia and Singapore have specific agency that will spearhead OHS-related matters. Table 2 shows the similarities and differences of aforementioned countries and the Philippines in terms of major stakeholders. Tripartite between government agencies, employers and employees are all done in these countries, and are done so effectively, with minimal overlap of their roles and responsibilities. Meanwhile, in the Philippines, there were a total of 27 Stakeholders identified according to their legal mandates. Twenty are government agencies, three (3) Professional bodies, two (2) international organizations, safety organization and academic institutions as a whole. Although the Philippines has the Inter-Agency Committee for Environmental Health, the occupational health is only

Table 1. List of Identified Stakeholders and their respective agencies, 2016

\section{Government Agencies}

(1) Department of Health (DOH)

(2) Department of Labor and Employment (DOLE)

(a) Occupational Safety and Health Center (OSHC)

(b) Bureau of Working Conditions (BWC)

(c) Bureau of Workers with Special Concerns (BWSC)

(d) Overseas Workers Welfare Administration

(3) Civil Service Commission (CSC)

(4) Dangerous Drugs Board (DDB)

(5) Department of Agriculture (DA)

(6) Department of Energy (DoE)

(7) Department of Environment and Natural resources (DENR)

(a) Environmental Management Bureau (EMB)

(b) Mines and Geosciences Bureau (MGB)

(8) Bureau of Fire Protection under the Department of Interior and Local Government

(9) Office of Civil Defense (OCD) under Department of National Defense (DND)

(10) Board of Investments (BOI) under the Department of Trade and Industry (DTI)

(11) Department of Transportation and Communication (DTC)

(a) Land Transportation Franchising and Regulatory Board (LTRFB)

(b) Land Transportation Office (LTO)

(c) Maritime Industry Authority (MAl)

(12) Philippine Coast Guard (PCG)

(13) Philippine Overseas Employment Administration (POEA)

Labor Organizations

(14) Federation of Free workers (FFW)

(15) Public Service Labor Independent Confederation

(16) Trade Union Congress of the Philippines (TUCP)

Employees' Compensation and Related Organizations

(17) Government Service Insurance System (GSIS)

(18) Employees' Compensation Commission (ECC)

(19) Philippine Health Insurance Corporation (PHIC)

(20) Social Security System (SSS)

\begin{tabular}{|c|c|c|}
\hline $\begin{array}{c}\text { Professional } \\
\text { Organizations }\end{array}$ & $\begin{array}{c}\text { International } \\
\text { Organizations }\end{array}$ & Others \\
\hline $\begin{array}{l}\text { (21) Occupational } \\
\text { Health Nurses } \\
\text { Association of } \\
\text { the Philippines } \\
\text { (OHNAP) } \\
\text { (22) Philippine } \\
\text { College of } \\
\text { Occupational } \\
\text { Medicine (PCOM) } \\
\text { (23) Safety } \\
\text { Organization } \\
\text { of the } \\
\text { Philippines Inc. }\end{array}$ & $\begin{array}{l}\text { (24) International } \\
\text { Labour } \\
\text { Organization } \\
\text { (ILO) } \\
\text { (25) World } \\
\text { Health } \\
\text { Organization } \\
\text { (WHO) and the } \\
\text { Environment } \\
\text { Division }\end{array}$ & $\begin{array}{l}\text { (26) Safety } \\
\text { Training } \\
\text { Organization } \\
\text { (27) } \\
\text { Academic } \\
\text { Institutions }\end{array}$ \\
\hline
\end{tabular}


Table 2. Comparison Between Philippines and other Countries on Stakeholders for Occupational Health and Safety, 2016

\begin{tabular}{|c|c|c|c|c|c|c|c|c|}
\hline \multirow[b]{2}{*}{ Country } & \multicolumn{8}{|c|}{ Stakeholders } \\
\hline & $\begin{array}{c}\text { Ministry of } \\
\text { Health }\end{array}$ & $\begin{array}{l}\text { Ministry of } \\
\text { Labor }\end{array}$ & $\begin{array}{l}\text { Ministry of } \\
\text { Industry }\end{array}$ & Workers & Employers & $\begin{array}{c}\text { Higher } \\
\text { Education } \\
\text { Institutions }\end{array}$ & $\begin{array}{c}\text { Professional } \\
\text { bodies }\end{array}$ & $\begin{array}{c}\text { *Interagency } \\
\text { body }\end{array}$ \\
\hline Finland & $\sqrt{ }$ & $\sqrt{ }$ & $x$ & $\sqrt{ }$ & $\sqrt{ }$ & $\sqrt{ }$ & $\sqrt{ }$ & \\
\hline Australia* & $x$ & $\sqrt{ }$ & $x$ & $\sqrt{ }$ & $\sqrt{ }$ & $x$ & $\sqrt{ }$ & $\sqrt{ }$ \\
\hline Singapore* & $x$ & $\sqrt{ }$ & $\sqrt{ }$ & $\sqrt{ }$ & $\sqrt{ }$ & $x$ & $\sqrt{ }$ & $\sqrt{ }$ \\
\hline Malaysia & $\sqrt{ }$ & $\sqrt{ }$ & $x$ & $\sqrt{ }$ & $\sqrt{ }$ & $x$ & $\sqrt{ }$ & \\
\hline Thailand & $\sqrt{ }$ & $\sqrt{ }$ & $\sqrt{ }$ & $\sqrt{ }$ & $\sqrt{ }$ & $x$ & $\sqrt{ }$ & \\
\hline Philippines & $\sqrt{ }$ & $\sqrt{ }$ & $\sqrt{ }$ & $\sqrt{ }$ & $\sqrt{ }$ & $\sqrt{ }$ & $\sqrt{ }$ & $\sqrt{ }$ \\
\hline
\end{tabular}

Note: ${ }^{*}=$ Australia has Safe Work Australia; Singapore has Work Health Safety Council and Institute; Philippines has IACEH-OH

$\sqrt{ }=$ Existent in the country but does not have an active role in $\mathrm{OHS}$

= Agencies are non-existent

a part of the task force, therefore the committee does not oversee all OHS-related matters.

There were 27 stakeholders who participated in the Key Informant Interviews. The topics on the questions were the following: (1) legal mandate, (2) roles and responsibilities, (3) information dissemination, (4) self-assessment on institution performance in fulfilling their roles and responsibilities, and (5) issues and gaps in the implementation in the country. In terms of the legal mandate, fourteen (14) stakeholders have full OHS legal provisions, while ten (10) are mandated to formulate programs and projects, and three (3) have no legal mandate on OHS.

Meanwhile, fourteen (14) stakeholders stated that their roles and responsibilities are focused more on OHS program and services implementation. Seven (7) are focused on capacity building, and six (6) for policy formulation.

On information dissemination, thirteen (13) stated that they utilize Print and broadcast media in cascading information throughout their clients and stakeholders.

From a scale of one (1) to ten (10) in terms of their agency's performance, the average scored garnered is 7.2 which is a more than satisfactory rate.

Stakeholders stated that there is a need in improving on working relationships and regionalization of agencies. Moreover, issues and gaps highlighted were: 1) lack of awareness for OHS in different workplaces, 2) a need for a comprehensive monitoring and evaluation system, 3) a need for clear delineation of roles and responsibilities of agencies, and 4) the need for efficient allocation and mobilization of resources. In order to strengthen their roles and responsibilities, stakeholders recommended agencies that can support them, these are: (1) Government Organizations and Government-Owned and Controlled Corporations, (2) Workers'Unions, (3) Employers'Unions, (4) Safety Training Organizations, and (5) Non-Government Organizations and Private Sector Organizations. The stakeholders also stated that collaborative efforts can be used for capacity building to improve the OHS implementation.

Through the reviewed relevant documents and key informant interviews, the conceptual framework for the National Occupational Health and Safety of the Philippines was realized. The stakeholders were assessed through the following processes: 1) implementation, monitoring and evaluation of OHS legislations, 2) provision of efficient and responsive OHS programs and services, and 3) monitoring and evaluation of OHS-related data. This framework will ultimately lead to outcomes that will impact on healthy workers and safe workplace.

During the workshop, there were only ten (10) InterAgency Committee for Environmental Health $(\mathrm{OH}$ subsector) stakeholders who attended. The following activities transpired: presentation of the review of the relevant documents, key informant interviews, proposed diagram and finalization of the stakeholders' roles and responsibilities. The finalized diagram (see figure 1) depicts three (3) converging circles that show the three general areas of function:

(1) The planning, implementation, monitoring, and evaluation of OHS policies and legislations. This includes tasks on OHS administration, enforcement and promotion.

(2) The provision of efficient and responsive OHS services. Activities included in this function are training provision, and research and development.

(3) The monitoring and evaluation of OHS-related data which mainly focuses on statistics-related activities.

Both the Legislative (Congress and Senate) and the Executive Branch of the Government influence the aforementioned responsibilities. Furthermore, note that ten (10) government agencies assume three (3) functions. Only one (1) agency works with two roles and eleven (11) agencies collectively assume only one role. Common issues were also identified during the workshop, such as unclear definition of roles and responsibilities, lack of coordination between agencies, and weak enforcement of OHS legislations.

\section{DISCUSSION}

There were 27 stakeholders identified, that has functions that revolve around three categories: (1) planning, implementation, monitoring, and evaluation of OHS 


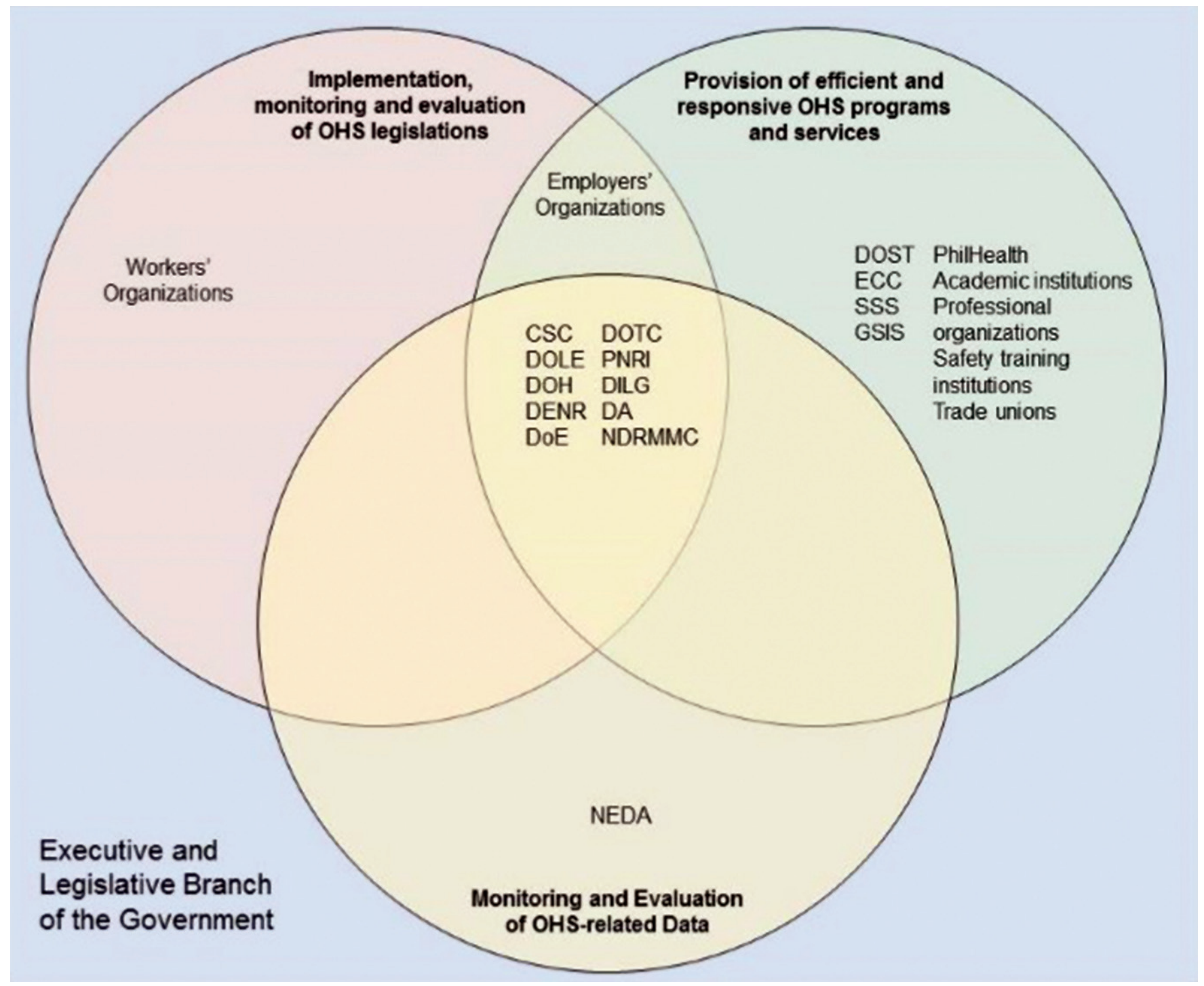

Figure 1. The Stakeholders Framework for National Occupational Health and Safety in the Philippines, 2015.

Notes: (1) Department of Health (DOH), (2) Occupational Safety and Health Center (OSHC), (3) Bureau of Working Conditions (BWC), (4) Bureau of Workers with Special Concerns (BWSC), (5) Overseas Workers Welfare Administration, all under the Department of Labor and Employment (DOLE), (6) Civil Service Commission (CSC), (7) Dangerous Drugs Board (DDB), (8) Department of Agriculture (DA), (9) Department of Energy (DoE), (10) Environmental Management Bureau (EMB), (11) Mines and Geosciences Bureau (MGB) both under the Department of Environment and Natural resources (DENR), (12) Bureau of Fire Protection under the Department of Interior and Local Government, (13) Office of Civil Defense (OCD) under Department of National Defense (DND), (14) Board of Investments (BOI) under the Department of Trade and Industry (DTI), (15) Land Transportation Franchising and Regulatory Board (LTRFB), (16) Land Transportation Office (LTO), (17) Maritime Industry Authority (MAI) under the Department of Transportation and Communication (DTC), (18) Philippine Coast Guard (PCG), and (19) Philippine Overseas Employment Administration (POEA) (20) Labor Organizations are the following: (a) Federation of Free workers (FFW), (b) Public Service Labor Independent Confederation, and (c) Trade Union Congress of the Philippines (TUCP). Moreover, agencies under the (21) Employees' Compensation and (22) Related Organizations: (a) Government Service Insurance System (GSIS), (b) Employees' Compensation Commission, (c) Philippine Health Insurance Corporation (PHIC), and (d) Social Security System (SSS). Professional Organizations include: (23) Occupational Health Nurses Association of the Philippines (OHNAP), (24) Philippine College of Occupational Medicine (PCOM), and (25) Safety Organization of the Philippines Incorporation

policies and legislations, (2) provision of efficient and responsive OHS services, and (3) monitoring and evaluation of OHS-related data. Moreover, the investigators were able to determine five (5) common gaps according to the results. These are: (1) lack of lead agency that will oversee all OHS initiatives; (2) lack of OHS mandate awareness on some agencies; (3) lack of clear delineation of roles and responsibilities among stakeholders; (4) poor coordination among government agencies; and (5) poor enforcement of OHS legislations. These results affect policy implementation and practice, as they all focus in the governance capabilities of the country. 
In the Philippines, although Inter-Agency Committee for Environmental Health (OH subsector) was established, the $\mathrm{OH}$ subsector only bears the responsibility for OHSrelated matters, and as such the committee does not fully function for OHS. Although, the Department of Labor and Employment is mandated to formulate policies and implement programs on occupational health and safety, they have other responsibilities such as ensuring that the labor code of the Philippines is implemented, and thus, is not fully dedicated for OHS.

The importance of a lead agency is highlighted in countries such as Singapore and Australia who have a separate inter-agency body that was established specifically to handle OHS. Singapore, through the Ministry of Manpower, created the Work Health and Safety Council and Institute, which advises the Ministry of Manpower regarding corrective measurements in addressing OHS concerns of the industries and country, as well as oversees compliance and policies delegated to be relevant and effective. The country's tripartite collaboration proved that innovating in the advancement of work safety and health in the country is efficient and effective. Australia established Safe Work Australia to oversee their OHS related matters nationally. Designated offices of different states work with Safe Work Australia to ensure that mandates are laid out across the country. This made Singapore and Australia's Occupational Health and Safety culture strong and effective. In addition, its formation became an avenue for a far greater coordination and cooperation between the government, employers and employees of their respective countries.

Meanwhile, Thailand's National Profile emphasizes on mandates and legislation of agencies that shall carry out OHS duties in the country. This ensures that agencies are able to provide services accordingly and efficiently in their mandates, and in turn cascaded to their constituents. This is similar to a book that emphasized on enterprise awareness. In which informed enterprises are most likely to change attitude towards OHS because they are able to determine that worker's health and safety plays an important part in productivity and economic sustainability. ${ }^{12}$

Other countries' roles and responsibilities are clearly delegated into policy enforcement, training, research and development and information management. Agencies from these countries range from the Ministry of Health to Social and Business partners. In which, social partners such as employers play as a counterpart of the government agencies. Moreover, agencies that assume more than three (3) roles do not exceed to ten (10). It is important to know that at some point, stakeholders play a vital role in the success or failure of implementation. Therefore, overlapping of roles among stakeholders, would be best at minimum. By doing so, development of policies and activities would not be redundant and easily cascaded to other agencies. In addition, clear delineation of roles, can bring about clear, concrete and actionable goals towards to a better policy implementation.
Malaysia's identified stakeholders are specifically mandated to coordinate with other agencies, for proper cascading of policies and activities designated to them. Coordination among agencies ensure efficiency of services, avoidance of duplication and improvement of equity. ${ }^{13}$ In support, coordination is an element of organization which seeks to ensure the subjects, objects and working processes are in place. It is important because the purpose of an organization is to have a clear coherence in sharing and coordination. ${ }^{14}$

As stated, there is poor enforcement of OHS legislations in the country. This could have risen from inadequate capacity and capability of various agencies in the Philippine setting. The importance of OHS legislation is to ensure that workers are protected and safe. In Australia, their Work Health and Safety (WHS) laws protect their people by imposing obligations on all parties who are in a position to contribute to the success of their companies. ${ }^{15}$ Some countries also have penalties regarding non-compliance of OHS legislations or standards. Locally, a bill championed by Senator Villanueva that would set out strict compliance of OHS standards and policies is in place. ${ }^{16}$ This will also adhere to the Labor code, that states employers must provide a healthy and safe working conditions for their employees. ${ }^{17}$

\section{CONCLUSION}

There were 27 stakeholders identified which are part of the Inter-Agency Committee for Environmental Health $(\mathrm{OH}$ subsector). Moreover, the gaps identified were centralized on governance concerns. These are: (1) Lack of a dedicated agency that will oversee all OHS initiatives across industries and sectors, (2) Inadequate awareness on OHS mandate of some agencies, (3) Unclear delineation of roles and responsibilities among stakeholders, (4) Poor coordination among government agencies, and (5) Poor enforcement of OHS legislations

The gaps identified affect policy implementation, and ultimately the implementation of OHS programs and services. It is imperative to note that, the overall involvement of the stakeholders matter in leading and driving the policies that will be translated into various programs and initiatives.

\section{RECOMMENDATIONS}

The purpose of developing a stakeholder framework is to address the occupational health and safety issues that the country faces. However, there were several gaps identified. In order to address these, the following recommendations are proposed:

(1) Strengthening the IACEH-OH subsector. Inclusion of other government and non-government agencies during decision-making will lessen the redundancy and strengthen the IACEH-OH functions. Moreover, the $\mathrm{OH}$ subsector could be the dedicated agency that would handle OHS-related matters across industries and 
sectors. In this way, matters are handled and overseen by one agency. In addition, by strengthening the subsector's function, inter-agency coordination, policy enforcement and information dissemination will be effectively performed.

(2) Strict implementation of OHS Legislations. This will ensure that employers follow the standards in protecting their workers and providing safe working conditions. The approval of the OHS bill will improve the implementation of OHS legislations.

It is imperative to note that decision-making is a shared responsibility by government, non-government agencies and professional bodies. These agencies must work hand in hand to be able to do their OHS functions well. Addressing the gaps, may not be the best retort to the weakened OHS implementation, but this could be the means of opening other opportunities in taking notice on the responsibilities of the stakeholders as primary implementers and leaders for occupational health and safety in the country.

In terms of methodology, the study only utilized review of relevant documents, key informant interviews and a workshop, therefore future studies may use other stakeholder analysis methods. Moreover, stakeholders should be encouraged to engage in policy formulation.

\section{Acknowledgments}

The investigators would like to acknowledge the project team that conducted these activities under the Department of Health-commissioned project entitled the "Strengthening of the National Occupational Health and Safety Program and Related Activities", last 2015.

\section{Statement of Authorship}

All authors have approved the final version submitted.

\section{Author Disclosure}

All authors have declared no conflict of interest.

\section{Funding Source}

This project was fully funded by the Department of Health, Republic of the Philippines.

\section{REFERENCES}

1. Alli, B. O. Fundamental Principles of Occupational Health and Safety. p.2 [Online]. 2008. [cited 2016 May] Available from http://www.ilo. org/wcmsp5/groups/public/@dgreports/@dcomm/@publ/documents/ publication/wcms_093550.pdf.
2. World Health Organization. (2012). National Profile of Occupational Health System in Finland. pp. 2-4 [Online]. 2012. [cited 2016 May]. Available from http://www.euro.who.int/_data/assets/pdf_ file/0016/160522/e96482.pdf.

3. World Health Organization. The WHO Health Systems Framework. pp. 2-3.

4. Department of Labour and Protection Welfare - Ministry of Labor. National Occupational Safety and Health Profile: Thailand. pp. 2-4 [Online]. 2015. [cited 2016 May] Available from http://www.ilo. org/wcmsp5/groups/public/---ed_protect/---protrav/---safework/ documents/policy/wcms_436936.pdf.

5. International Labour Organization. (2014). Workplace Safety and Health Profile: Singapore. [Online]. 2014. [cited 2016 May] Retrieved from http://www.ilo.org/wcmsp5/groups/public/---ed_ protect/---protrav/---safework/documents/policy/wcms_436953.pdf.

6. Ministry of Health. Occupational Safety and Health Master Plan for Malaysia. pp. 2-4 [Online]. 2015. [cited 2016 May]. Available from http://www.ilo.org/wcmsp5/groups/public/---asia/---ro-bangkok/--sro-bangkok/documents/policy/wcms_182420.pdf.

7. Ministry of Human Resources. Occupational Safety and Health Master Plan for Malaysia. pp. 2-4 [Online]. 2015. [cited 2016 May]. Available from http://www.ilo.org/wcmsp5/groups/public/---asia/--ro-bangkok/---sro-bangkok/documents/policy/wcms_182420.pdf.

8. Safe Work Australia. pp. 2-4 [Online]. [cited 2016 May]. Available from http://www.safeworkaustralia.gov.au/sites/swa/model-whs-laws/ guidance/volunteers/pages/whs-duties-organisations.

9. Department of Health. Philippine National Environmental Health Executive Plan (2008-2013). Department of Health, Philippines, 2010. Document. pp 3-5.

10. Department of Health. Occupational Health and Safety Profile of the Philippines. Department of Health and Department of Labor and Employment, Philippines, 2015. Document. pp 3-5.

11. BSR. Stakeholder Mapping. p.6 [Online]. 2011. [cited 2016 May] Available from http://www.bsr.org/reports/BSR_Stakeholder_ Engagement_Stakeholder_Mapping.final.pdf

12. Hughes, P., Ferret, E. (2010). Introduction to International Health and Safety and work. p.473. Routledge, 2010.

13. Akl EA, El-Jardali F, Bou Karroum L. et.al. (2015). Effectiveness of Mechanisms and Models of Coordination between Organizations, Agencies and Bodies Providing or Financing Health Services in Humanitarian Crises: A Systematic Review. [Online]. 2015. [cited 2017 July]. Available from https://www.ncbi.nlm.nih.gov/pmc/ articles/PMC4558048/.

14. Vanagas, R, Stankevič, J. (2014). Impact of Coordination for Organization Process. [Online]. 2014. [cited 2017 July]. Available from https://www.mruni.eu/upload/iblock/3eb/8\%20IE_Vanagas_STR_ EN.pdf.

15. Workplace OHS. (n.d) Legislation. [Online] [cited 2017 July] Available from http://workplaceohs.com.au/legislation.

16. Senate of the Philippines (2017). Sen. Joel Villanueva's opening remarks during the hearing on occupational safety, workers' right to selforganize, and wage rationalization. [Online] 2017. [cited 2017 July]. Available from http://www.sen ate.gov.ph/press_release/2017/0517 villanueva1.asp.

17. The Labor Code of the Philippines Presidential Decree No. 442, as Amended [Online]. Available from http://www.chanrobles.com/ legal4labor4.htm. 